\title{
Estimating dispersal and gene flow in the neotropical freshwater turtle Hydromedusa maximiliani (Chelidae) by combining ecological and genetic methods
}

\author{
Franco L. Souza ${ }^{1}$, Anderson F. Cunha ${ }^{2}$, Marcos A. Oliveira ${ }^{2}$, Gonçalo A.G. Pereira ${ }^{2}$ and Sérgio F. dos Reis ${ }^{3}$ \\ ${ }^{1}$ Departamento de Biologia, Centro de Ciências Biológicas e da Saúde, Universidade Federal de Mato \\ Grosso do Sul, Campo Grande, Mato Grosso do Sul, Brazil. \\ ${ }^{2}$ Departamento de Genética, Instituto de Biologia, Universidade Estadual de Campinas, Campinas, \\ São Paulo, Brazil. \\ ${ }^{3}$ Departamento de Parasitologia, Instituto de Biologia, Universidade Estadual de Campinas, Campinas, \\ São Paulo, Brazil.
}

\begin{abstract}
Hydromedusa maximiliani is a vulnerable neotropical freshwater turtle endemic to mountainous regions of the Atlantic rainforest in southeastern Brazil. Random amplified polymorphic DNA (RAPD) was used to estimate the gene flow and dispersal for individuals inhabiting rivers and streams within a drainage. Nine primers generated 27 scoreable bands, of which 9 (33\%) were polymorphic and produced 12 RAPD phenotypes. The gene flow estimates $(\mathrm{Nm})$ among turtles inhabiting different rivers and streams were variable, ranging from 0.09 to 3.00 (mean: 0.60 ). For some loci, the rates of gene flow could offset population differentiation $(\mathrm{Nm}>1)$, whereas for others random genetic drift could result in population divergence $(\mathrm{Nm}<1)$. Since the genetic variation of this turtle seems to be structured according to the natural hierarchical system of rivers and streams within drainages, management programs involving translocations between different regions across the geographical range of $H$. maximiliani should be viewed with caution.
\end{abstract}

Key words: Hydromedusa maximiliani, dispersal, gene flow, conservation.

Received: April 2, 2002; accepted: June 5, 2002.

\section{Introduction}

The neotropical freshwater turtle Hydromedusa maximiliani (Chelidae) is endemic to the Atlantic forest of the coastal region of southeastern Brazil, with a geographical distribution ranging from the State of Espírito Santo to the State of São Paulo (Ernst and Barbour, 1989; Iverson 1992). Throughout its range, the distribution of $H$. maximiliani is disjunct, occurring in isolation at elevations above $600 \mathrm{~m}$. Locally, its habitat is topologically complex, with sequences of ridges and valleys each drained by river and stream systems (Souza, 1995).

Capture-recapture studies have shown that these turtles have limited dispersal ability, with a mean daily displacement of 2 m (Souza 1995; Souza and Abe, 1997a). Dispersal over longer distances is apparently limited to the rainy season, when temporary or intermittent water systems

Send correspondence to Sérgio Furtado dos Reis. Departamento de Parasitologia, Instituto de Biologia, Universidade Estadual de Campinas, Caixa Postal 6109, 13083-970 Campinas, São Paulo, Brazil. E-mail: sfreis@ unicamp.br. are connected with the main watercourses (Souza and Abe, 1997a). The observed limited dispersal suggests that each H. maximiliani population inhabits a specific river within a given drainage system, and this hypothesis was addressed in a preliminary work on the population genetic structure of the species, which indicated a substantial partitioning of molecular variation across rivers and streams inhabited by this turtle (Souza et al., 2002). These findings of population structure on a small spatial scale defined by the complex topographical features of the species' habitat, a region topologically complex, with ridges and valleys drained by numerous rivers and streams (Pfeifer et al., 1986; Souza and Abe 1998), could imply that there is little or no gene flow among turtles inhabiting different water courses or distinct drainage. In this study, we used random amplified polymorphic DNA (RAPD) markers (Williams et al., 1993) to assess levels of gene flow among local $H$. maximiliani populations, and briefly discuss the conservation and management implications of our findings. 


\section{Material and Methods}

Field work was conducted from November 1998 to November 1999 at the Parque Estadual de Carlos Botelho (PECB), state of São Paulo, southeastern Brazil (2400'$\left.24^{\circ} 15^{\prime} \mathrm{S}, 47^{\circ} 45^{\prime}-48^{\circ} 10^{\prime} \mathrm{W}\right)$. The PECB is a protected reserve that encompasses over 37,000 ha of intact tropical montane rain forest typical of southeastern Brazil (Whitmore, 1990; Veloso et al., 1991). In this study, an area of approximately 500 ha containing eight rivers and streams (1-8) was surveyed (Figure 1). This 500 ha area was the same as used in previous studies of this species' natural history [see Souza and Abe (1995, 1997a,b, 1998) for a more detailed description of the area]. Three sites were defined within these drainage based on the spatial hierarchy of the main rivers and their tributaries: site A (which included river 1 ), site $\mathrm{B}$ (which included rivers $2,3,4$, and 5), and site $\mathrm{C}$ (which included rivers 6, 7, and 8) (Figure 1).

Turtles $(n=25)$ were hand-caught and 200-300 $\mu \mathrm{L}$ of blood was drawn from the scapula vein/brachial artery (Avery and Vitt, 1984) using a 26-gauge needle and a $1 \mathrm{~mL}$ syringe. The blood samples were immediately preserved in $1 \mathrm{~mL}$ of absolute ethanol (Miyaki et al., 1997) in plastic vials and stored at room temperature. The turtles were released at the point of capture after blood sample collection.

Genomic DNA was extracted from the blood samples by two successive organic extractions with phenol:chloroform:isoamyl alcohol as outlined by Bruford et al. (1992) and Miyaki et al. (1998), and then precipitated with 1/10 volume of $1 \mathrm{M}$ sodium acetate ( $\mathrm{pH}$ 5.3) and two volumes of $100 \%$ ethanol. The quality of the extracted DNA was evaluated in agarose gels $(0.7 \%)$ stained with ethidium bromide and quantified by comparison with DNA standards run in the same gel. DNA was diluted to a working concentration of approximately $0.6 \mathrm{ng} / \mu \mathrm{L}$.

Eighty primers (Operon Technologies, Inc.; Alameda, California, EUA) were initially screened for consistently reproducible and scoreable amplified bands. Nine primers that met these criteria were used to analyze the DNA samples from the 25 individuals captured in the studied area. The polymerase chain reaction (PCR) was performed in a Perkin-Elmer GeneAmp ${ }^{\mathrm{TM}}$ PCR system 9700 with a total volume of $12.5 \mu \mathrm{L}$ containing $10 \mathrm{mM}$ Tris $\mathrm{HCl}$ (pH 8.4), $50 \mathrm{mM} \mathrm{KCl}, 3.5 \mathrm{mM} \mathrm{MgCl} 2,1 \mu \mathrm{L}$ of each dNTP, $2 \mu \mathrm{L}$ of primer, $0.3 \mu \mathrm{L} \mathrm{Taq}$ polymerase, $1.2 \mathrm{ng}$ of genomic DNA and sterile water. Negative controls in which water was substituted for DNA were run to check for the possibility of contamination. Reproducibility was gauged by comparing duplicate reactions, which were usually adjacent to one another in the thermocycler, and products were run side-by-side on the same gel. The reaction conditions involved initial denaturation of DNA for $2 \mathrm{~min}$ at $94{ }^{\circ} \mathrm{C}$, 39 cycles of $1 \mathrm{~min}$ denaturation at $94^{\circ} \mathrm{C}, 1 \mathrm{~min}$ annealing at $40{ }^{\circ} \mathrm{C}, 2 \mathrm{~min}$ extension at $72^{\circ} \mathrm{C}$, and one 5 min cycle at $72{ }^{\circ} \mathrm{C}$ for final extension. The amplification products were

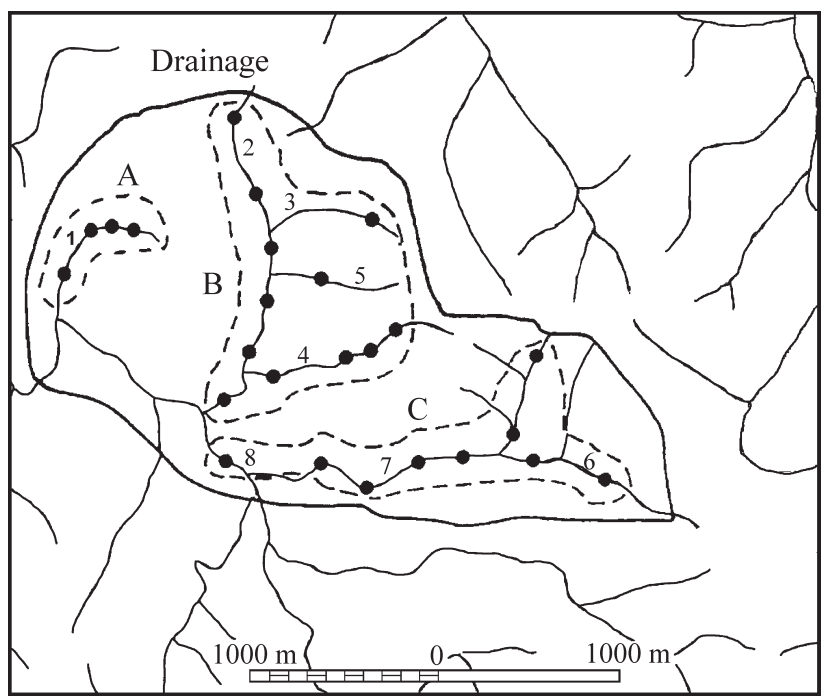

Figure 1 - Map of the study site at Parque Estadual de Carlos Botelho, state of São Paulo, southeastern Brazil. The sample drainage for Hydromedusa maximiliani is showed as a heavy line with numbers 1-8 indicating rivers and streams surveyed. Dotted lines show the three sample sites (A, B, C) defined according to the spatial hierarchy of the main rivers and their tributaries Dots indicate individual collection sites.

separated on $1.3 \%$ agarose gels stained with ethidium bromide, run in buffer $1 \mathrm{X}$ TAE at a constant voltage of $80 \mathrm{~V}$ for $5 \mathrm{~h}$. Monochrome photographic negatives were taken of the gels and the individual profiles were scored by two of the authors (FLS and AFC) for the presence/absence of fragments for each primer (see Souza et al., 2002, for a full description of these methods).

Allele frequencies were estimated for standard genetic analysis of population structure. Most $(\sim 90 \%)$ alleles amplified by arbitrarily primed PCR segregate as dominant markers. Since these RAPD alleles are revealed as the presence or absence of a band, it is not generally possible to distinguish heterozygous individuals from those homozygous for the dominant allele at such loci because both have the "band present" phenotype (Ferreira and Grattapaglia, 1998). We assumed that all loci considered in our analyses met this criterion and that the genotypes were in HardyWeinberg equilibrium. Allele frequencies were obtained using the asymptotically unbiased estimator, $\hat{\mathrm{q}}$, derived by Lynch and Milligan (1994), as follows

$$
\hat{\mathrm{q}}=\sqrt{\widehat{\mathrm{x}}}\left(1-\frac{\operatorname{Var}(\hat{\mathrm{x}})}{8 \hat{\mathrm{x}}^{2}}\right)
$$

where $\hat{\mathrm{X}}$ is the frequency of the null allele calculated as the square root of the frequency of the null phenotype (i.e., absent band).

The analysis of molecular variance, AMOVA (Excoffier et al., 1992) was used to measure the variation in allelic frequencies for each locus among populations of turtles inhabiting different rivers and streams from the sampled drainage. Gene flow $(\mathrm{Nm})$ was estimated from $F$-statistics, $F_{S T}$, as a measure of the genetic interaction 
among populations, indicating the number of immigrants per population per generation (Slatkin, 1985, 1987). We used the formula $F_{S T}=1 /(4 N m+1)$, where $N$ is the local population size and $m$ is the average rate of immigration. For this estimate, we assumed neutrality, negligible mutation and a stepping-stone population structure model (Kimura and Weiss, 1964). This assumption was crucial because the relation of $F_{S T}$ to underlying microevolutionary parameters changes with different models of population structure (Slatkin, 1985, 1987). Contingency chi-square values were calculated to determine whether $F_{S T}$ estimates varied from zero (significant population differentiation), using the formula $\chi^{2}=2 N F_{S T}(k-1)$, where $N$ is the total sample size, and $k$ is the number of alleles; $\mathrm{df}=(k-1)(m-1)$, where $m$ is the number of samples (in this case, the number of sites within sampled drainage) (Johnson and Black, 1991).

\section{Results}

Nine of the 80 primers used yielded band patterns that were clear and could be scored with confidence. These primers produced 27 potentially scoreable bands (range $1-6$; mean 3), of which nine bands (33\%) were polymorphic and produced 12 RAPD phenotypes. The estimated allele frequencies at RAPD-encoding loci from these nine polymorphic bands varied among rivers and streams, indicating that most loci were spatially structured (Table I) and endemic to some rivers and streams. Locus 2 was found only for site A (river 1), which was the river located farthest west in this drainage. Two unique alleles were found for turtles inhabiting river 4 at site B (loci 5 and 9), while one unique allele (locus 8) was found for individuals from river 2 (site B). One allele, locus 1 , was the most widespread allele and was detected at all three sites, including rivers $2,4,7$, and 8 (Table I).

The estimated $F_{S T}$ for each locus ranged from 0.077 to 0.743 (Table II), and only one locus (locus 7) showed no significant difference among populations $(\mathrm{p}>0.05)$. The overall differentiation $\left(F_{S T}=0.293\right)$ among populations of
Table II - Among population differentiation $\left(F_{S T}\right)$ and gene flow estimates $(\mathrm{Nm})$ of RAPD allele frequencies for nine variable loci (L) from Hydromedusa maximiliani specimens inhabiting a drainage in the Parque Estadual de Carlos Botelho, state of São Paulo, southeastern Brazil. d.f.: degrees of freedom.

\begin{tabular}{lcrccc}
\hline Locus & $F_{S T}$ & \multicolumn{1}{c}{$\chi^{2}$} & d.f. & $\mathrm{p}$ & $N m$ \\
\hline L1 & 0.1411 & 7.06 & 2 & 0.05 & 1.52 \\
L2 & 0.4620 & 23.10 & 2 & 0.001 & 0.29 \\
L3 & 0.3858 & 19.29 & 2 & 0.001 & 0.39 \\
L4 & 0.7428 & 37.14 & 2 & 0.001 & 0.09 \\
L5 & 0.1864 & 9.32 & 2 & 0.01 & 1.09 \\
L7 & 0.0770 & 3.85 & 2 & 0.05 & 3.00 \\
L8 & 0.1864 & 9.32 & 2 & 0.01 & 1.09 \\
L9 & 0.1864 & 9.32 & 2 & 0.01 & 1.09 \\
L10 & 0.2726 & 13.63 & 2 & 0.01 & 0.67 \\
Total & 0.2934 & 132.03 & 18 & 0.0001 & 0.60 \\
\hline
\end{tabular}

turtles inhabiting different rivers and streams from the sampled drainage was significant $\left(\chi_{18}^{2}=132.03\right.$; $\left.p<0.0001\right)$, indicating variation among populations. The average $\mathrm{Nm}$ estimate was 0.60 (range $=0.09-3.00)$.

\section{Discussion}

The combination of ecological and biogeographical processes is an important mechanism for shaping the genetic structure of populations. Thus, life-traits (mating systems, dispersal ability), historical events (fragmentation, range expansion, colonization), and landscape matrix (mountain ridges, watersheds) may provide the background for understanding the geographic structure of genetic variation among populations (Templeton et al., 1995).

$\mathrm{Nm}$ estimates of more than one immigrant into the average deme per generation, as calculated for five loci (loci $1,5,7,8$, and 9), indicated that gene flow among populations inhabiting different rivers and streams was sufficient to deter population differentiation if they were at equilibrium between migration and random genetic drift (Wright,

Table I - Band frequencies (locus: L) among nine oligonucleotide primers for $H$. maximiliani sampled from eight rivers and streams which formed the three sites (A, B, and C) of a drainage in the Parque Estadual de Carlos Botelho. The values indicate the presence frequency of variable bands $(n=$ sample size)

\begin{tabular}{|c|c|c|c|c|c|c|c|c|c|c|}
\hline Site & River & L1 & L2 & L3 & L4 & L5 & L7 & L8 & L9 & L10 \\
\hline $\mathrm{A}(n=4)$ & $1(n=4)$ & 1.00 & 0.75 & 1.00 & 1.00 & 1.00 & 0.00 & 1.00 & 1.00 & 1.00 \\
\hline \multirow[t]{4}{*}{$\mathrm{B}(n=12)$} & $2(n=6)$ & 0.83 & 1.00 & 1.00 & 1.00 & 1.00 & 0.00 & 0.83 & 1.00 & 1.00 \\
\hline & $3(n=1)$ & 1.00 & 1.00 & 1.00 & 1.00 & 1.00 & 0.00 & 1.00 & 1.00 & 1.00 \\
\hline & $4(n=4)$ & 0.50 & 1.00 & 1.00 & 1.00 & 0.75 & 0.00 & 1.00 & 0.75 & 0.75 \\
\hline & $5(n=1)$ & 1.00 & 1.00 & 1.00 & 1.00 & 1.00 & 0.00 & 1.00 & 1.00 & 0.00 \\
\hline \multirow[t]{3}{*}{$\mathrm{C}(n=9)$} & $6(n=2)$ & 1.00 & 1.00 & 1.00 & 1.00 & 1.00 & 0.00 & 1.00 & 1.00 & 1.00 \\
\hline & $7(n=6)$ & 0.67 & 1.00 & 0.67 & 0.17 & 1.00 & 0.17 & 1.00 & 1.00 & 1.00 \\
\hline & $8(n=1)$ & 0.00 & 1.00 & 0.00 & 0.00 & 1.00 & 1.00 & 1.00 & 1.00 & 1.00 \\
\hline
\end{tabular}


1931; Slatkin, 1985, 1987). In contrast, $N m$ values for four loci (loci 2, 3, 4, and 10) were less than one, implying that the differentiation among populations could have occurred through random genetic drift alone (Slatkin, 1985, 1987). Overall, the $N m$ estimate of 0.589 indicated that the $H$. maximiliani populations inhabit different rivers.

Population structure bears an inverse relationship with the dispersal capability of organisms (Hartl and Clark, 1997), and the observed pattern of $H$. maximiliani population structure on a local spatial scale (Souza et al., 2002) is consistent with the known dispersal behavior of the species. Direct and indirect methods for estimating gene flow (Slatkin, 1987) in this species yielded similar results. Estimates of dispersal for $H$. maximiliani based on mark-recapture data (direct method) gathered during a 1993-1994 study (Souza and Abe, 1997b) showed that the movement of individuals was fairly restricted, with a mean daily displacement of two meters, suggesting that turtles from each river and stream within a drainage could be structured in as a metapopulation (Hanski and Simberloff, 1997). Indeed, individuals from which blood samples were taken for the present study in 1999 were found only a few meters from the site where they had been marked in 1993-1994.

The hypothesis of a metapopulation structure was confirmed by indirect (genetic) methods. The fact that several alleles were unique for rivers and streams within a drainage indicated that, because of the turtles' limited dispersal, mating must be restricted to related individuals, which would facilitate the development of a local genetic structure. Furthermore, the molecular markers produced high $F_{S T}$ values and low $N m$ values, indicating low gene flow among turtles inhabiting different rivers and streams. Templeton et al. (1990) found that mitochondrial DNA haplotypes in strictly aquatic salamanders were partitioned according to rivers within drainage, in a similar manner to the partitioning of RAPD variation for $H$. maximiliani. For organisms with a sedentary nature and low dispersal ability, such as snails, the genetic structuring of populations on small geographic scales is frequently detected (Johnson and Black, 1991; Arnaud et al., 1999, 2001), and could have originated from limited gene flow among populations.

Additional sampling of drainages and rivers and streams within drainage, as well as the use of mitochondrial and nuclear sequence markers will be necessary to estimate effective population sizes, population genealogies and other aspects fundamental to $H$. maximiliani conservation. These genetic analyses are important for the protection and management of this turtle species because such information could be useful in determining options for translocations. The genetic variation in this turtle species is structured according to the natural hierarchical system of rivers and streams within drainage, and limited gene flow is detected among populations from different rivers and streams. Thus, each watershed may harbor endemic populations, which suggests a strong degree of genetic structure and differentiation in the geographical range of the species.

\section{Acknowledgements}

The authors thank E.L.A. Monteiro-Filho and L.C. Duarte for helpful comments and criticisms on the manuscript, S. Hyslop for reviewing the English of the manuscript, and C.Y. Miyaki for assistance in the early stages of this study. The Instituto Florestal provided logistic support and P.P. Soares and A. John provided assistance in the field. J.R. Somera helped with the line drawings. This study was funded by the Fundação de Amparo à Pesquisa do Estado de São Paulo, Brazil (FAPESP, grant 00/00805-9) and Fundo de Apoio ao Ensino e à Pesquisa, Universidade Estadual de Campinas, São Paulo, Brazil (FAEP, grant 0023/00). FLS was the recipient of a post-doctoral fellowship from FAPESP (contract number 99/02761-0). SFR is partially supported by a research fellowship from the Conselho Nacional de Desenvolvimento Científico e Tecnológico (CNPq), Brazil.

\section{References}

Arnaud JF, Madec L, Bellido A and Guiller A (1999) Microspatial genetic structure in the land snail Helix aspersa (Gastropoda: Helicidae). Heredity 83:110-119.

Arnaud JF, Madec L, Guiller A and Bellido A (2001) Spatial analysis of allozyme and microsatellite DNA polymorphism in the land snail Helix aspersa (Gastropoda: Helicidae). Mol. Ecol. 10:1563-1576.

Avery HW and Vitt LJ (1984) How to get blood from a turtle. Copeia 1984:209-210.

Bruford MW, Hanotte O, Brookfield JFY and Burke T (1992) Single-locus and multilocus DNA fingerprinting. In: Hoelzel AR (ed) Molecular Genetic Analysis in Conservation, Oxford, pp 225-270.

Ernst CH and Barbour RW (1989) Turtles of the World. Smithsonian Institution Press, Washington, D.C., 313pp.

Excoffier L, Smouse PE and Quattro JM (1992) Analysis of molecular variance inferred from metric distances among DNA haplotypes: application to human mitochondrial DNA restriction data. Genetics 131:479-491.

Ferreira ME and Grattapaglia D (1998) Introdução ao Uso de Marcadores Moleculares em Análise Genética. Embrapa, Brasília, 220 pp.

Hanski I and Simberloff D (1997) The metapopulation approach, its history, conceptual domain, and application to conservation. In: Hanski IA and Gilpin ME (eds) Metapopulation Biology: Ecology, Genetics, and Evolution. Academic Press, New York, pp 5-26.

Hartl D and Clark AG (1997) Principles of Population Genetics. Sinauer, Sunderland, $389 \mathrm{pp}$.

Iverson JB (1992) A Revised Checklist with Distribution Maps of the Turtles of the World. Privately printed, Richmond, $363 \mathrm{pp}$.

Johnson MS and Black R (1991) Genetic subdivision of the intertidal snail Bembicium vittatum (Gastropoda: Littorinidae) varies with habitat in the Houtman Abrolhos Islands, Western Australia. Heredity 67:205-213. 
Kimura M and Weiss GH (1964) The stepping stone model of population structure and the decrease of genetic correlation with distance. Genetics 49:561-576.

Lynch M and Milligan BG (1994) Analysis of population genetic structure with RAPD markers. Mol. Ecol. 3:91-99.

Myiaki CY, Pereira SL, Biasia I and Wajntal A (1997) DNA fingerprint applied to parrot captive breeding programs. Ararajuba 5:127-133.

Miyaki CY, Matioli SR, Burke T and Wajntal A (1998) Parrot evolution and paleogeographical events: mitochondrial DNA evidence. Mol. Biol. Evol. 15:544-551.

Pfeifer RM, Carvalho WA, Silva DA, Rossi M and Mendicino LF (1986) Levantamento semi-detalhado dos solos do Parque Estadual de Carlos Botelho, SP. Bol. Tec. I. F., São Paulo, 40:75-109.

Slatkin M (1985) Gene flow in natural populations. Ann. Rev. Ecol. Syst. 16:393-430.

Slatkin M (1987) Gene flow and the geographic structure of natural populations. Science 236:787-792.

Souza FL (1995) História natural do cágado Hydromedusa maximiliani (Mikan 1820) no Parque Estadual de Carlos Botelho, SP, região de Mata Atlântica (Reptilia, Testudines, Chelidae). MS Thesis, Universidade Estadual Paulista, Rio Claro.

Souza FL and Abe AS (1997a) Population structure, activity, and conservation of the neotropical freshwater turtle, Hydromedusa maximiliani, in Brazil. Chel. Conserv. Biol. 2:521-525.
Souza FL and Abe AS (1997b) Seasonal variation in the feeding habits of Hydromedusa maximiliani (Testudines, Chelidae). Bol. Asoc. Herpetol. Esp. 8:17-20.

Souza FL and Abe AS (1998) Resource partitioning by the neotropical freshwater turtle, Hydromedusa maximiliani. J. Herpetol. 32:106-112.

Souza FL, Cunha AF, Oliveira MA, Pereira GAG, Pinheiro HP and dos Reis SF (2002) Partitioning of molecular variation at local spatial scales in the vulnerable neotropical freshwater turtle, Hydromedusa maximiliani (Testudines, Chelidae): implications for conservation of aquatic organisms in natural hierarchical systems. Biol. Conserv. 104:119-126.

Templeton AR, Shaw K, Routman E and Davis SK (1990) The genetic consequences of habitat fragmentation. Ann. Miss. Bot. Gard. 77:13-27.

Templeton AR, Routman E and Phillips CA (1995) Separating population structure from population history: a cladistic analysis of the geographical distribution of mitochondrial DNA haplotypes in the tiger salamander, Ambystoma tigrinum. Genetics 140:767-782.

Veloso HP, Rangel-Filho ALR and Lima JCA (1991) Classificação da Vegetação Brasileira Adaptada a um Sistema Universal. Instituto Brasileiro de Geografia e Estatística, Rio de Janeiro, 123 pp.

Whitmore TC (1990) An Introduction to Tropical Rain Forests. Oxford University Press, Oxford, 296 pp.

Williams JGK, Hanafey MK, Rafalski JA and Tingey SV (1993) Genetic analysis using random amplified polymorphic DNA markers. Met. Enzymol. 218:704-740.

Wright S (1931) Evolution in Mendelian populations. Genetics 16:97-159. 